\title{
Using Story Mapping Technique in Teaching Writing Skills at SMAN 1 Palopo
}

\author{
${ }^{1}$ Ashar Daung Allo, 2Wahibah, and ${ }^{3}$ Magfirah Thayyib \\ 1,2.3Institut Agama Islam Negeri Palopo (IAIN Palopo), Palopo, Indonesia \\ asharplp22@gmail.com ${ }^{1}$ \\ *wahibah@iainpalopo.ac.id ${ }^{2}$ \\ magfirah thayyib@iainpalopo.ac.id ${ }^{3}$
}

\begin{abstract}
The purpose of this research was to find out whether the use of story mapping technique effective to improve students' writing recount text at the first grade of SMAN 1 Palopo. This research applied quasi experimental. The research was carried out in two classes, experimental and control classes. The population of this research was the first grade students of SMAN 1 Palopo. The samples of this research were Class X MIPA 2 as a control class and Class X IPA 3 as experimental class. The sampling technique in this research was random sampling. The instrument of this research was writing test. The writer gave pretest and posttest to the students. The data was analyzed by using SPSS 20.The result of this research showed that the use of story mapping technique in teaching writing recount text is effective. It could be seen from the result of calculation that the students' score in experimental class which was higher than students' score in control class. The mean score of posttest in experimental class was higher than the mean score of pretest (76.7667>61.6667). While in control class the mean score of posttest was also higher than the mean score of pretest (71.0667>67.8000). It means that there was significant difference between the students' score in teaching writing recount text by using story mapping technique and students' score in teaching writing recount text without using story mapping technique at the first grade of SMAN 1 Palopo.

Key Words: Writing, Technique, Recount Text.
\end{abstract}

\section{INTRODUCTION}

English is very important in daily life. As an international language, it plays an important role in communication which many people are involved in. English has many connections with various aspects of human being. There are four skills that have to be mastered. They are speaking, writing, reading and listening. Listening and reading are receptive skills, because student just receive and understand language without producing it. These skills are known as passive skills. On the other hand, speaking and writing are productive skills because students are producing a language. They are also known as active skills (Irvy, 2020). Writing is a skill that must be improved by the students. In the process of teaching and learning writing, some teachers do not know how to teach writing appropriately (Yahya et al., 2020). The teacher usually only asks the students to write as much as possible without knowing how to make the students do the instruction. This fact motivated the researchers to focus on encouraging the students to write recount text or to tell stories of their past experience in the written form (Anwar et al., 2020).

However not all students can adopt the methods used by the teacher. Learning with the same technique make students bored and have no idea to write. That is why teachers must master various methods and creativity in teaching in order to assist student in learning process. There are many factors affecting the students in writing. The difficulty 
to get ideas, low in grammar skills, lacked of vocabulary are the problem in the classroom. These problems are the causes of students' poor writing ability. The activities done by the teacher did not encourage the students to learn and write more. The teacher usually just asks the students to write based on the instruction, but it is very difficult for them to write directly in an empty paper. Asking the students to rearrange words into sentences or sentences into paragraphs cannot stimulate their willingness to write (Anggraeni et al., 2020). Based on the observation in SMAN 1 Palopo that had been done and had been explained above, the low writing ability was affected by some factors and that would be impossible to analyze all of them one by one in this research. Story mapping is the best solution to solve students 'problems in writing recount text, because it greatly facilitates students in organizing students' stories into a mapping.

\section{METHODS}

The research applied a quasi-experimental design. The research involved in two groups, experimental and control group. The experimental group received treatment by using story mapping technique, the control group received treatment by using conventional method.

\begin{tabular}{|c|c|c|c|}
\hline Group & Pre & Treatment & Post \\
\hline $\begin{array}{l}\text { Treatment class } \\
\text { Control class }\end{array}$ & $\begin{array}{l}\mathrm{O}_{1} \\
\mathrm{O}_{2} \\
\end{array}$ & $\mathrm{X}$ & $\begin{array}{l}\mathrm{O}_{3} \\
04 \\
\end{array}$ \\
\hline
\end{tabular}

Where:
Treatment class
: Experimental method
Control class
: Conventional method
$\mathrm{O}_{1}$
: Result of Pre-test (in experimental method)
$\mathrm{O}_{2}$
: Result of Pre-test (in conventional method)
$\mathrm{X}$
: Treatment (story mapping technique for treatment class)
$\mathrm{O}_{3}$
: Result of Post-test (in experimental method)
$\mathrm{O}_{4}$
: Result of Post-test (in conventional method).

\section{Variable}

This research consists of two variables. Dependent variable is ability of the student in writing recount text. Independent variable is story mapping technique

\section{Population and sample}

The writer took the first grade students of SMAN 1 Palopo as a population. The writer took two classes as sample, X MIA 2 and X MIA 3 of SMAN 1 Palopo academic year 2019/2020. There were 60 students (30 students of control class and 30 students of experimental class). Random sampling was used to take a sample of this research

\section{Research Instrument}

The data collected by using writing test. The writer used writing recount text to know ability of the students in English before and after giving treatment. The writing test is about their experiences in the most memorable experience.

\section{Technique of Data Analysis}

The data were analyzed by using Statistical Produce and Service Solution (SPSS) ver. 
20 for windows. it would be tabulated into independent sample test, mean score, standard deviation, and standard error deviation.

RESULTS

The students score of experimental class

Table 1. the students' pre-test result in experimental class

\begin{tabular}{cccc}
\hline Classification & Score & frequency & Percentage \\
\hline Excellent & $90-100$ & 0 & $0 \%$ \\
Good & $80-89$ & 0 & $0 \%$ \\
Adequate & $70-79$ & 8 & $26.66 \%$ \\
Inadequate & $60-69$ & 12 & $40 \%$ \\
Unacceptable & Below 60 & 10 & $33.33 \%$ \\
\hline
\end{tabular}

Table 1 shows that there are 30 students observed in experimental class before giving treatment. There are eight students $(26.66 \%)$ who get adequate score, twelve students $(40 \%)$ who get inadequate score, ten students $(33.33 \%)$ who get unacceptable score.

Table 2. the students' post-test result in experimental class

\begin{tabular}{cccc}
\hline Classification & Score & Frequency & Percentage \\
\hline Excellent & $90-100$ & 6 & $20 \%$ \\
Good & $80-89$ & 5 & $16.66 \%$ \\
Adequate & $70-79$ & 12 & $40 \%$ \\
Inadequate & $60-69$ & 7 & $23.33 \%$ \\
Unacceptable & Below 60 & 0 & $0 \%$ \\
\hline
\end{tabular}

The table shows that there are 30 students observed in experimental class after giving treatment. There are six students (20\%) who get excellent score, five students (16.66\%) who get good score, twelve students (40\%) who get adequate score, seven students $(23.33 \%)$ who get inadequate score.

The students score in control class

Table 3. The students' pre-test result in control class

\begin{tabular}{cccc}
\hline Classification & Score & Frequency & Percentage \\
\hline Excellent & $90-100$ & 0 & $0 \%$ \\
Good & $80-89$ & 1 & $3.33 \%$ \\
Adequate & $70-79$ & 13 & $43.33 \%$ \\
Inadequate & $60-69$ & 12 & $40 \%$ \\
Unacceptable & Below 60 & 4 & $13.33 \%$ \\
\hline
\end{tabular}

Table 3 shows that there are 30 students observed in control class before teaching without using story mapping technique. There is one student (3.33\%) who got good score, thirteen students (43.33\%) who get adequate score, twelve students (40\%) who get inadequate score, five students $(13.33 \%)$ who get unacceptable score.

Table 4. The students' post-test result in control class

\begin{tabular}{cccc}
\hline Classification & Score & Frequency & Percentage \\
\hline Excellent & $90-100$ & 1 & $3.33 \%$ \\
Good & $80-89$ & 3 & $10 \%$ \\
Adequate & $70-79$ & 13 & $43.33 \%$ \\
\hline
\end{tabular}




$\begin{array}{cccc}\text { Inadequate } & 60-69 & 11 & 36.66 \% \\ \text { Unacceptable } & \text { Below 60 } & 2 & 6.66 \%\end{array}$

Table 4 shows that there are 30 students observed in control class after teaching using conventional method. There is one student (3.33\%) who get excellent score, three students (10\%) who get good score, thirteen students (43.33\%) who get adequate score, eleven students $(36.66 \%)$ who get inadequate score, two students $(6.66 \%)$ who get unacceptable score.

\section{The students' mean score in pre-test and post-test and post-test in experimental class and control class}

Table 5. The mean score and standard deviation of students' pre-test and post-test in control class

\begin{tabular}{ccccccccc}
\hline \multicolumn{8}{c}{ Descriptive Statistics } \\
\hline & N & Minimum & Maximum & Sum & Mean & $\begin{array}{c}\text { Std. } \\
\text { Deviation }\end{array}$ \\
\cline { 2 - 8 } & Statistic & Statistic & Statistic & Statistic & Statistic & $\begin{array}{c}\text { Std. } \\
\text { Error }\end{array}$ & Statistic \\
\hline Pretest & 30 & 48.00 & 82.00 & 2034.00 & 67.8000 & 1.47967 & 8.10449 \\
Posttest & 30 & 55.00 & 90.00 & 2132.00 & 71.0667 & 1.60955 & 8.81587 \\
$\begin{array}{c}\text { Valid N } \\
\text { (listwise) }\end{array}$ & 30 & & & & & & \\
\hline
\end{tabular}

Table 6. The mean score and standard deviation of students' pre-test and post-test in experimental class

\begin{tabular}{cccccccc}
\multicolumn{7}{c}{ Descriptive Statistics } \\
& N & Min. & Max. & Sum & Mean & $\begin{array}{c}\text { Std. } \\
\text { Deviation }\end{array}$ \\
\cline { 2 - 8 } & Statistic & Statistic & Statistic & Statistic & Statistic & Std. Error & Statistic \\
\hline Pretest & 30 & 42.00 & 78.00 & 1850.00 & 61.6667 & 1.72162 & 9.42972 \\
Posttest & 30 & 61.00 & 93.00 & 2303.00 & 76.7667 & 1.64190 & 8.99304 \\
Valid N & 30 & & & & & & \\
(listwise) & 30 & & & & & & \\
\hline
\end{tabular}

Table 5 and table 6 show that the distinction between the pre-test and post-test mean score and standard deviation. The scores of control class after teaching using conventional method show good progress from 82 becomes 90 and the scores of experimental class after giving treatment (using story mapping) show very good progress from 78 becomes 93. The standard deviation of control class in pre-test and post-test is 8.81 and the standard deviation of experimental class in pre-test and post-test is 8.99. To know whether the control class and experimental class are significantly different, and also to know acceptability of hypothesis of this research, the researcher use test analysis and calculate it by using SPSS 20 . The result could be shown in the table of group statistic and independent sample test. 
Copyright (C) The Author(s)

Vol. 1, No. 2, October 2020

$e$-ISSN: 2723-4126

\section{The calculation of t-test pre-test and post-test in experimental and control class}

Table 7. the probability value of t-test of pre-test in experimental and control classes Independent Samples Test

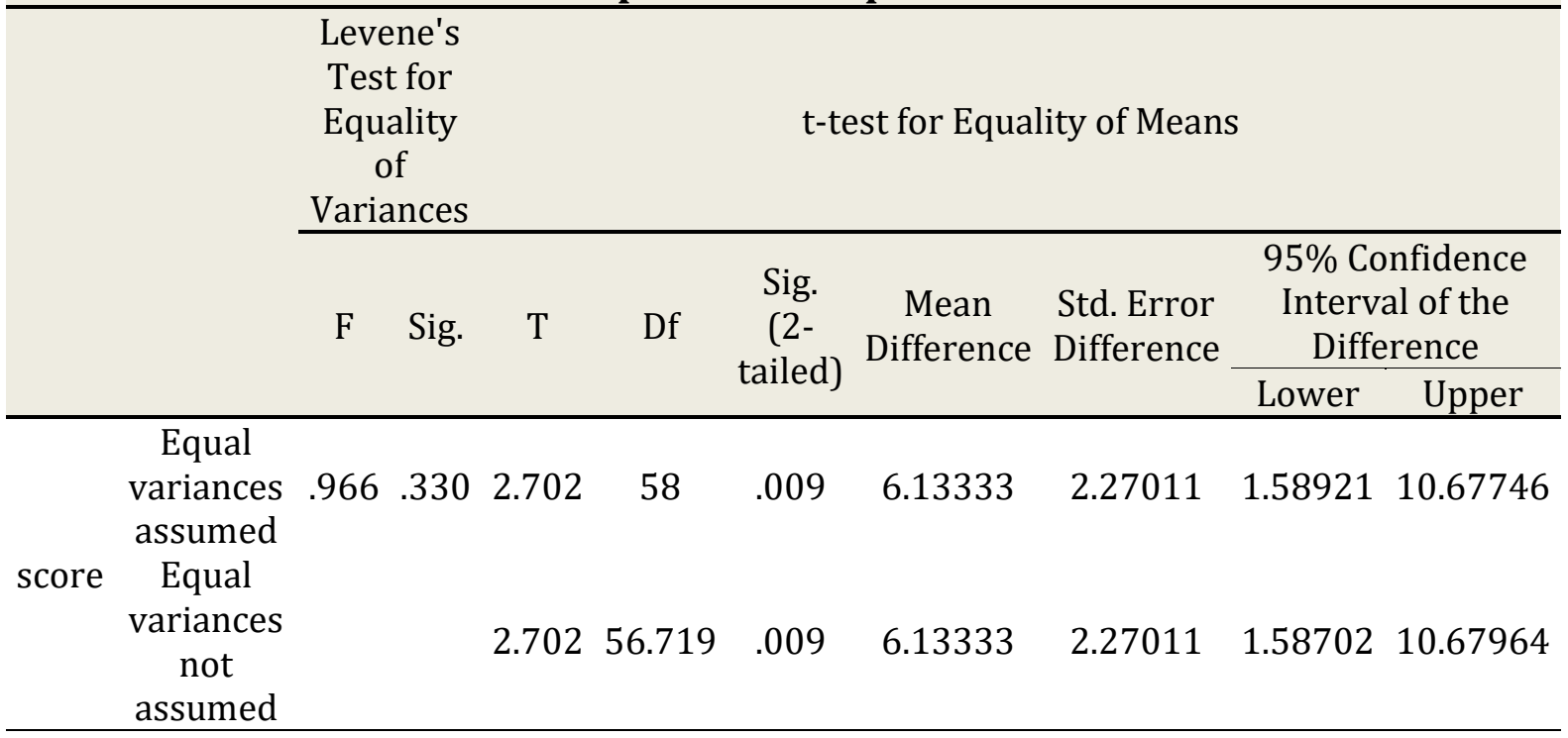

Table 7 show that the mean score of difference between control class and experimental class did not have significant difference

Table 8. The probability value of t-test of post-test in experimental and control class

\begin{tabular}{|c|c|c|c|c|c|c|c|c|c|c|}
\hline \multicolumn{11}{|c|}{ Independent Samples Test } \\
\hline & & $\begin{array}{l}\text { Leve } \\
\text { Tes } \\
\text { Equ } \\
\text { Varia }\end{array}$ & $\begin{array}{l}\text { ne's } \\
\text { for } \\
\text { ality } \\
\text { f } \\
\text { ances }\end{array}$ & & \multicolumn{6}{|c|}{ t-test for Equality of Means } \\
\hline & & \multirow[t]{2}{*}{$\mathrm{F}$} & \multirow[t]{2}{*}{ Sig. } & \multirow[t]{2}{*}{$\mathrm{t}$} & \multirow[t]{2}{*}{ Df } & \multirow{2}{*}{$\begin{array}{l}\text { Sig. } \\
(2- \\
\text { tailed })\end{array}$} & \multirow[t]{2}{*}{$\begin{array}{c}\text { Mean } \\
\text { Difference }\end{array}$} & \multirow[t]{2}{*}{$\begin{array}{l}\text { Std. Error } \\
\text { Difference }\end{array}$} & \multicolumn{2}{|c|}{$\begin{array}{l}\text { 95\% Confidence } \\
\text { Interval of the } \\
\text { Difference }\end{array}$} \\
\hline & & & & & & & & & Lower & Upper \\
\hline \multirow[b]{2}{*}{ Score } & $\begin{array}{c}\text { Equal } \\
\text { variances } \\
\text { assumed }\end{array}$ & .026 & .872 & $3 . \overline{185}$ & 58 & .002 & -7.30000 & 2.29212 & 11.88818 & $\begin{array}{c}- \\
2.71182\end{array}$ \\
\hline & $\begin{array}{c}\text { Equal } \\
\text { variances } \\
\text { not } \\
\text { assumed }\end{array}$ & & & $\begin{array}{c}- \\
3.185\end{array}$ & 57.989 & .002 & -7.30000 & 2.29212 & $\begin{array}{c}- \\
11.88820\end{array}$ & $\begin{array}{c}- \\
2.71180\end{array}$ \\
\hline
\end{tabular}

The table 8 show that the probability value was lower than alpha $(\alpha)(0.002<0.05)$ which means that there is significant difference in post-test. It indicated that the alternative hypothesis (H1) is accept and the null hypothesis (H0) is reject it show that the use of story mapping strategy effective to improve the students' writing and give significantly contribution the students' writing skill. 


\section{DISCUSSION}

There are five items of writing assessment that is used by the researcher to analyze the data namely content, organization, vocabulary, language use and mechanics. Based on the students' score in pretest, for both experimental and control class had a little different significant before giving treatment. Students' score of both classes in post test had significantly difference. In experimental class, there is item had significant result in writing between pre-test and post-test. Organization criteria in pre-test, the data shows that most of students got good to average score. There are thirteen students who got good to average score, eleven students who got fair to poor score, six students who got very poor score. Organization criteria in post-test, the data shows that most of students got good to average score. There are seven students who got excellent to very good score, nineteen students who got good to average score, four students who got fair to poor score. This is because students found it easier to group storyline from the beginning, the middle, and ending, because they had already been made their own storyline in the story mapping technique.

Based on result of the data analysis above shows that use story mapping technique effective to improve students' writing skill, it can be seen on the table before after giving treatments continually (by using story mapping technique) the mean score students' experimental class is $\mathbf{7 7 . 9 0}$ while students' control class is treat by conventional teaching or teaching without using story mapping technique is 71.06 . Besides that, the students score in post test of experimental class is higher than the students score in post test of control class that is $96>90$. It means that after giving treatment using story mapping technique is better than teaching without using story mapping technique. Pertaining to the result of the research, it is consisted with the theory proposed by Li (2007) who says story mapping is used to help the students to plan their writing because a story map contains the components of a story such as settings, events, and re-orientation. This practically can be their guidance to process their ideas before writing a well-organized text. ( $\mathrm{Li}, 2007$ )

In fact, teaching writing recount text by using story mapping technique at SMAN 1 Palopo, the students got significant improvement in their score writing recount text. Therefore, it could be stated that story mapping technique in teaching learning of writing have solved the students' writing problem and increase the students' writing skill for the first grade of the students at SMAN 1 Palopo. So, the hypothesis proposed in this research which says "story mapping technique effective to improve the student ability to write recount text" is accepted.

\section{CONCLUSION}

Based on the findings and discussion that had been presented in the previous chapter, it can be concluded that there is significant differences in learning result of the students who learned writing through story mapping technique with the students who took the learning with conventional method. Based on the data analysis the probability value was lower than alpha $(\alpha)(0.002<0.05)$ which means that there is significant difference in post-test. It indicated that the alternative hypothesis (H1) is accept and the null hypothesis (H0) is reject it show that the use of story mapping strategy effective to improve the students' writing and give significantly contribution the students' writing skill. The mean score of post-test was higher than the mean score of pre-test (76.7667>61.6667). While in control class, the mean score of post test was also higher than the mean score of pretest that $(71.0667>67.8000)$. Based on data analysis it can concluded that teaching writing recount text by using story mapping technique is 
effective to improve the students' ability. It can be proved that the students score in experimental class higher than students in control class.

\section{REFERENCES}

Anderson, A, \& Anderson, K. (2002). Text types in English 3. South Yara: MacMillan Education Australia PTY LTD

Anggraeni, W., Wahibah, \& Assafari, A. F. (2020). Teachers' Strategies in Teaching Speaking Skills at SMAN 1 Palopo. FOSTER: Journal of English Language Teaching, 1(1), 83-97. https://doi.org/10.24256/foster-jelt.v1i1.9

Anwar, L., Furwana, D., \& Iksan, M. (2020). Developing Reading Worksheet for Tenth Grade Students of SMA Negeri 4 Palopo. FOSTER: Journal of English Language Teaching, 1(1), 1-8. https://doi.org/10.24256/foster-jelt.v1i1.2

Akbar, Muhammad, 2008, Improving studentss writing skill through pair interview at the eleventh year students of SMAN 2 PALOPO, a thesis STAIN PALOPO 2008

Byrne, Donn. 1984. Teaching Writing Skills-new edition. London: Longman

Bram, Barly. 1995. Write well .Yogyakarta: Kanisius

Brown, H. Douglas. 1994. Teaching by Principles: An Interactive Approach to Language Pedagogy. Englewood Cliff: Prentice Hall.

Chen S, Zhou J. 2010. Creative Writing Strategies of Young Children: Evidence from a Study of Chinese Emergent Writing. Amsterdam: Elseiver.

Fromkin, Victoria and Robert Rodman, 1993, an introduction to language, fifth edition, Harcourt brace Jovanovich college publisher

Flynn, Naomi \& Rhona Stainthorp. The Learning and teaching of reading and Writing. West Sussex: Whurr Publisher, 2006.

Hartono, R. (2005). Genre of texts. Semarang: English Department Faculty of Language and Art Semarang State University.

Hedge, Tricia. Resource books for Teachers. Hong Kong: Oxford University press, 1988.

Heaton J.B, writing English language test (new edition). (Longman inc. new York, 1988), p.135

Harmer, Jeremy. 2001. How to Teach English: An Introduction to the Practice of English Language Teaching. Malaysia: Longman.

Irvy, I. I. (2020). Understanding the Learning Models Design for Indonesian Teacher. International Journal of Asian Education, 1(2), 95-106. https://doi.org/10.46966/ijae.v1i2.40

Leo Sutanto, English for academic purpose, essay writing, Penerbit andi, p.1

Li, D. (2007). Story mapping and its effect on the writing fluency and word diversity of students with learning disabilities, Learning Disabilities: A Contemporary Journal, 5(1), 42-50.

Nilmah, 2009, contribution of parallel writing technique to develop student's writing skill 
at the eleventh year students of SMAN BUPON, a thesis STAIN PALOPO

Oshima \& Hogue. 1997. Introduction to Academic Writing-Second Edition. New York: Longman

Raimes, Ann. Techniques in Teaching Writing. New York: Oxford University Press, 1983.

Rahmat Idul, 2011, Improving Students' Writing at the third year students of SMPN 8 PALOPO through describing picture in pairs, a thesis STAIN PALOPO.

Richards, Jack C. \& Renandya, Willy A. 2002. Methodology in Language Teaching.

New York: Cambridge University Press.

Wahyuni Dini, 2015, Using Peer Teaching Strategy To Improve The Students Ability To Write Recount Text At The Tenth Year Students Of SMKN 1 MAPPADECENG, IAIN PALOPO.

Wardiman Anton, dkk, 2008, English in focus for grade VIII junior high school (SMP/MTS), Jakarta: Pusat Perbukuan,

Weigle, Sara Cushing. 2002. Assessing Writing. Cambridge: Cambridge University Press.

Yunda Riska, (2017), Improving Students' Ability in Writing Recount using anecdote technique, Syiah Kuala University, Banda Aceh.

Zygouris, Coe V \& Glass, 2004. Story Mapping. FOR-PD's Reading strategy of the month.

Yahya, A., Jaya, F. A. I., \& Jufriadi. (2020). National Examination in SMPN 2 Palopo: A Case Study on Students' Readiness in English Test. International Journal of Asian Education, 1(2), 107-116. https://doi.org/10.46966/ijae.v1i2.38 